\title{
THE APPLICATION OF INSTRUCTIONAL MANAGEMENT BASED LESSON STUDY AND ITS IMPACT WITH STUDENT LEARNING ACHIEVEMENT
}

\author{
Imam Gunawan \\ Department of Educational Management, State University of Malang, Indonesia \\ imam.gunawan.fip@um.ac.id
}

\begin{abstract}
The purpose of this study is: (1) to describe the process of instructional management based lesson study; and (2) improving of student achievement by applying instructional management based lesson study. The research method used is a classroom action research, which is implemented with two cycles, namely Cycle I and Cycle II. The research instrument is the observation sheet of lesson study and test. Data analysis is the analysis of variance paired-samples t test formula with the SPSS PASW Statistics 18. Subjects of the study were 31 students of the Class Management course. The result of the research shows that: (1) the process of instructional management based on lesson study is cyclical i.e. lesson plan, learning implementation (do, open class), and learning evaluation (see); and (2) there is improvement of student achievement by applying instructional management based lesson study.
\end{abstract}

Keywords: instructional management, lesson study, student achievement

\section{INTRODUCTION}

Instructional management is the process of empowering all educational resources to achieve learning objectives. Operational instructional management is the implementation of management functions on learning components, namely: students, teachers, goals, materials, methods, tools, and evaluation (Rahayu, 2015). Instructional management is an activity to plan teaching and learning programs, implement teaching and learning process, and assess the process and learning outcomes, and the develop of classroom management (Danarwati, 2016). Lecturers in designing the instructional should pay attention to the alignment of materials, media, and methods to achieve lecture objectives. The ability of lecturers to manage instructional is the ability to plan, implement, and evaluate students in the learning process (Danarwati, 2016). Instructional management is a series of activities: (1) instructional plan, is syllabus, lesson plan, and teaching materials; (2) instructional implementation, encompassing methodology and instructional design; and (3) assessment of learning, concerning lattice, grain verification, and assessment aspect (Widodo, 2016; Gunawan, 2014).

The teachers approach to instructional management sets the tone for the overall classroom atmosphere and ultimately student behavior stressors (Martin, et al., 2012). Instructional management includes student control, instructional style, setting rules, and the regulation of student misbehaviors (Sass, et al., 2016). Instructional design and resources had been made to include scaffolding learner participation in a discussion forum (Gasevic, et al., 2016). Stated differently, what a teacher believes is the best behavior and instructional management style may not be realized depending on the class environment (Martin and Sass, 2010). Personal factors such as professional commitment proved to be important trait for an effective instructional management (Khan, 2012). To improve the quality of learning, lesson study activities become one of the alternatives that can be implemented by a lecturer. Lesson study originated in Japan as an approach to support the continuing professional development of teachers (Leavy and Hourigan, 2016). Lesson study is a collaborative activity of lecturers designing learning and evaluating the success of teaching strategies to improve the quality of learning process and student learning outcomes.

Lesson study requires them to come together and work interdependently to support student learning in the very practice of teaching, thus helping teachers' experience different types of knowledge in a coherent and related whole (Murata, 2010). Lecturers in lesson study collaboratively plan, teach, and observe learning activities. Lesson study is a model of professional development through continuous learning, based on the principle of collegiality and mutual learning to build the learning community (Rahardjo, 2012). Lesson study can act as a vehicle to promote meaningful learning and knowledge development among preservice teachers (Leavy and Hourigan, 2016). Lesson study is not a method or learning strategy, but lesson study activities can apply various methods or learning strategies. Lesson study is a structured approach to teacher learning, and certain common elements are necessary in order to justify calling it lesson study (Bjuland and Mosvold, 2015).

Student achievement describes students' mastery of the learned materials which can be seen from the cognitive, psychomotoric, and affective aspects (Gunawan, et al., 2014). Learning achievement assesses the students' understanding of the attributes, functions and relationships between objects, and the objectives of the object-based programming class by asking questions (Jang, et al., 2015). The role of lecturers in improving student achievement cannot be ignored. The teacher abilities have a negligible impact on average student achievement (Grönqvist and Vlachos, 2016). That the formation of close, low conflict, teacher-student relationships mediates the relation between effortful control and academic achievement (Hernández, et al., 2017). Student achievement becomes a measure of student academic success. Students' academic success and persistence has tended to concentrate on variables such as first 
generation status, socioeconomic status, and prior school achievement (Fong, et al., 2017).

The effects on student achievement of the changes in the teachers' formative classroom practice that followed the professional development input (Andersson and Palm, 2017). Teachers can influence student achievement, not only directly, but also indirectly via peer effects (Feng and Li, 2016; Grönqvist and Vlachos, 2016; Gunawan, et al., 2014). The amount of change in the outcome variable (e.g., student achievement) is directly proportional to the change in a context, input, or classroom process variable (e.g. school size, teacher efficacy, quality of instruction, student time-on-task) (Huitt, et al., 2009). The integration of technology into classroom instruction if appropriately implemented has strong and positive impact on students' achievement (Olelewe and Agomuo, 2016). Lesson study-based instructional management can be used as a lecturer effort to improve student achievement. Collaboration during lesson planning in lesson study was a significant predictor of student achievement (Reeves, et al., 2017). Teacher evaluation systems across the country have been revised with a renewed concentration on the impact of teacher quality on student achievement (Rury, 2013; Tygret, 2017). The research questions of this study, is: (1) how the process of instructional management based lesson study; and (2) whether the application of instructional management based lesson study can improve student's learning achievement?

\section{METHODS}

This study was conducted using a classroom action research design. Classroom action research is used because this research seeks to improve teaching performance of lecturers that is by improving student achievement in lectures. Lectures are conducted with lesson study. Lesson study is a form of research (Yoshida and Fernandez, 2016). The stages in the lesson study are implementationally similar to the classroom action research or action research cycle (Kemmis and McTaggart, 2014). Lesson study is conducted by integrating classroom action research cycle, namely: (1) stage plan, model lecturer with observer lecturer planning action; (2) stage do, model lecturers carry out lecture activities and observed by the observer lecturer; And (3) stage see, the model lecturer with the observer lecturer to reflect and evaluate the lectures that have been implemented.

The implementation of classroom action research by combining the lesson study in this research was carried out with two cycles, namely Cycle I and Cycle II. Classroom action research is implemented in the class of Class Management course, Department of Educational Administration, State University of Malang. The subjects are 31 students' participants in course. The research instrument used is the observation of lesson study and test. The lesson study observation sheet contains the following statement: (1) whether the student is learning about the topic of the course; (2) students who cannot attend lectures; (3) why the student cannot learn well; and (4) the effort of lecturers in encouraging students who are not active to learn.
The test instrument is used to measure student achievement. The test is given to the student after the lecture in each cycle. Data analysis is the analysis of variance paired-samples $t$ test formula with the SPSS PASW Statistics 18. Paired-samples t test is compare the differences in the means of the paired samples (Sarstedt and Mooi, 2014). Paired-samples t test was performed on two paired samples, paired samples defined as a sample with the same subject but experienced two different treatments or measurements, such as subject A will receive treatment I and then get treatment II (Santoso, 2000).

\section{RESULT}

\section{Instructional Management Based Lesson Study}

Lesson study based learning process based on basically refers to process management which includes learning planning, learning implementation, and learning evaluation. Learning planning is seen in the activities: (1) model lecturers and observer lecturers jointly develop lesson plan which refers to annual program; (2) identification of materials, media, and lecture methods that will be implemented in the open class; (3) determine the planned learning model in each cycle; and (4) determine the time allocation for each lecture activity. Lecture in every cycle, model lecturer apply cooperative learning model, which is in Cycle I apply cooperative learning model type Two Stay Two Stray, and in Cycle II combine two learning model that is Cooperative Integrated Reading and Two Stay Two Stray.

Implementation of learning in each cycle is: (1) lecture activities consisting of preliminary activities, core activities, and closing activities; and (2) the grouping of students in each cycle to support the application of cooperative learning model used. The grouping of students aims to assign students tasks, i.e. each group gets the task of discussing the material with group discussion first before discussed in class discussion. Students in class discussions are given the opportunity to ask questions, answer questions, or respond to the results of other group discussions. Model lecturers on implementing the activities provide reinforcement of the lecture material, giving appreciation and reinforcement to the group that is discussing correctly against the course material, and also explaining the material in more detail if there are groups that are not appropriate in discussing it.

Evaluation of learning appears in the activities: (1) every cycle of model lecturers and observer lecturers carry out reflection on lectures activities that have been implemented by model lecturers; and (2) appraisal by lecturer model on student activity in instructional. Reflection on the implementation of learning refers to the observation sheet of lesson study. The observation sheet of lesson study contains a description of observations by observer lecturers when conducting observation instructional. The observer lecturer at the reflection stage gives advice to the model lecturer in order to develop the next instructional activity. 


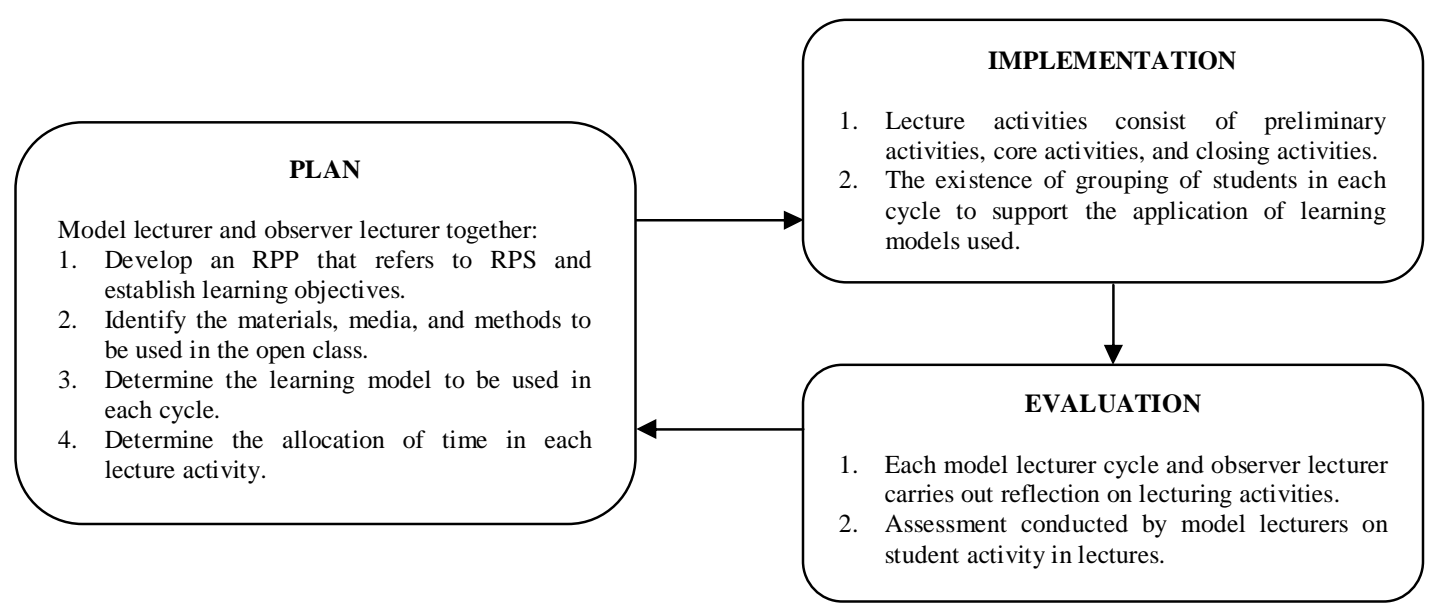

Figure 1 The Process of Instructional Management Based Lesson Study

If it refers to the above explanation, it can be argued that the process of lesson study-based instructional management is from activities: (1) learning plan; (2) implementation of learning activities; and (3) evaluation of learning activities. The process of instructional management based lesson study refers to cyclical management processes, starting from plan, implementation, and evaluation. The process of instructional management based lesson study as illustrated in Figure 1.

\section{Improvement of Student Learning Achievement}

In accordance with the purpose of research, lecturers apply instructional management based lesson study to improve student achievement of participants in the course of Class Management, with the number of students 31 participants. Here is described the results of the implementation of lesson study combined with classroom action research and scores obtained by students in each cycle.

Cycle I

Implementation of lesson study in Cycle I, first lecturer model make annual program and lesson plan. After the model lecturers make annual program and lesson plan, lesson study activity begins, i.e. implementing open lesson that is the plan phase. After that, carry out lecture activities (phase of do) with open class. Next perform the see phase with open lesson.

\section{Plan Phase}

This stage aims to produce a lecture design that can learn students effectively and generate student activeness in learning. Model lecturers and observer lecturers at the planning stage collaboratively share ideas and ideas in developing lesson plan to produce ways of organizing teaching materials, learning process, and preparation of teaching aids.

The agreement generated at the stage plan are: (1) learning model that will be used is Two Stay Two Stray; (2) learning materials is the basic concept of classroom management; (3) using observation sheet of student activeness in giving opinion; (4) using the rubric of student writing record; (5) learning tool that will be used is laptop and liquid centralium display (LCD); and (6) instructional media used is the material of impressions about the basic concept of class management materials in the form of Microsoft Power Point (ppt). Lecturer observers before carry out phase of do, prepare material and media to be used.

Implementation Phase (Do)

This phase is the application of the agreement made by the faculty team at the phase plan. Suggestion from the observer lecturer is taken into consideration of the model lecturer to carry out the learning in the classroom. Model lecturers implement learning in accordance with lesson plan. Observer lecturers who make observations during the learning process take place. The learning phase briefly consists of three stages. This stage is the syntax of Two Stay Two Stray learning model.

Stage 1 lecturers divide the students into 7 groups; each group will discuss different subthemes with other groups by discussion method. Phase 2 seven groups are divided into small groups, namely groups A and B, Group A assigns information on the results of the group discussion (stay) to the visiting group, while group B is in charge of finding information from other groups (strays) and the results are recorded. Initiating the syntax of the Two Stay Two Stray Learning Model Group B visits group A with a rotating system, which is 7 rounds. The 7 th round of group B will return to their respective groups (early groups). Phase 3 of each group conveys the results of the discussion, and other groups listen and give inputs or questions to the group that presents the results of the discussion, the early group did not present the theme, but presented the theme of the other group.

\section{Reflection Phase (See)}

Model lecturer together with observer lecturer at stage see together discusses the observation result of learning activity. The reflection performed together with the observer resulted in the finding that in general the learning has run smoothly. Learning activities conducted in the classroom in accordance with the planned, especially on the implementation of Two Stay Two Stray learning model syntax, model lecturers implement the syntax of Two Stay Two Stray learning model correctly. The implementation of learning activities refers to the learning objectives. The model 
lecturer directs the learning consistently, manages the course time correctly, conditioned the class to be interactive, and explains if there is material that the students have not understood yet.

Act Phase

Cycle I reflection results into consideration of follow up activities (act) for improvement of learning. The corrective actions to the RPP which refers to the results of reflection are: (1) assigning each student tasks during the learning process with the form of student worksheet; and (2) implementing Cooperative Integrated Reading learning model which enables each student to have their own activity in the lecture. The results of this reflection and follow-up plan are outlined in the improvement of learning by preparing the lesson plan that will be applied in Cycle II.

\section{Cycle II}

The implementation of the lesson study in Cycle II is the result of follow-up from Cycle I. Cycle II attempts to improve learning by taking into account the problems that arise in Cycle I. The model lecturer makes the RPP by considering the results of reflection on Cycle I and the suggestions from the observer lecturer.

Plan Phase

The planning phase of Cycle II is modified from lesson plan based on reflection on Cycle I. The previous model lecturer makes lesson plan by considering the reflection result from Cycle I. The agreement resulted in the plan phase is: (1) the implementation of learning by combining the two learning models namely Cooperative Integrated Reading and Two Stay Two Stray; (2) learning materials are aspects and functions of classroom management; (3) using Student Worksheet; (4) using observation sheet of student activeness in giving opinion; (5) using the rubric of students' writing record; (6) learning tools that will be used are laptop and LCD; and (7) the instructional media used is the material of impressions on the aspect and class management functions in the form of Microsoft Power Point (ppt). Furthermore the model lecturer prepares the learning tool for Cycle II.

\section{Implementation Phase (Do)}

This stage is the application of the agreement made by the faculty team at the stage of the plan. Model lecturers implement learning in accordance with the planned RPP. Other lecturers act as observers who make observations during the learning process takes place. The learning phase briefly consists of four stages. This stage is a combination of the steps of Cooperative Integrated Reading and Two Stay Two Stray learning model.

Stage 1 lecturers divide the students into 9 groups; each group will discuss different themes with other groups. Stage 2 lecturers provide discourse / clipping according to the learning topic to each student according to the theme of the group. Students in groups, tasked to find the main idea and provide responses from the results of group analysis of discourse / clipping. Each student recorded the results of his group discussion.
Phase 3 nine groups are subdivided into small groups, namely groups A and B. Group A is tasked with providing information on the results of group discussion (stay) to the visiting group, while group B is in charge of finding information from other groups (strays) and the results are recorded. Stage 4 of each group conveys the outcome of the discussion, and the other groups listen and provide input or question to the group presenting the results of the discussion. The early group did not present the theme, but presented the theme of another group.

Reflection Phase (See)

Model lecturers together with observer lecturer at stage see together discuss the results of observations during the learning process takes place. The reflection performed together with the observer resulted in the finding that in general learning was well under way. The observer lecturer responded that the model lecturer implemented the innovative learning and enabled all students in the lecture. This is because every student is working on a Student Worksheet that has been designed by a model lecturer. In addition, according to the topic discussed in one of its subtopics is the innovation of education in the classroom, the model lecturer not only gives an example by explaining it, but also become an example by applying innovative learning model and able to activate the students.

Model lecturers also direct the learning consistently, manage the lecture time appropriately, and conditioned the class to be interactive and able to activate the students. This is different from the do on Cycle I that is less in optimizing the individual activities of students in the group, in this Cycle II is every student is active in completing tasks individually and groups with learning support tools in the form of Student Worksheet.

\section{Act Phase}

Based on the results of reflection on Cycle II follow-up (act) to improve the quality of learning continuously. The corrective actions to the lesson plan that refers to the results of reflection are: (1) modify the learning method used; and (2) model lecturers at the beginning of the lesson provide students with more detailed explanations on how to work on a Student Worksheet. Student Worksheet prepared by observer lecturers should be made simpler and there are instructions for doing.

\section{Student Learning Achievement Every Cycle}

Students in each cycle are given test questions to measure their understanding of the course material. The results of the tests obtained by the students are a learning achievement in the learning activities. Table 1 shows student achievement in each cycle. Based on Table 1 can be seen in Cycle I: maximum score 80, minimum score 47, and average 61.87. And in Cycle II: maximum cycle 93 , minimum score 73 , and average 83.55. The mean score of students in Cycle II (83.55) is higher than Cycle I (61.87). The result of variance analysis of paired-samples t test formula with the help of SPSS PASW Statistics 18 found that the significance value of 0.000 (Table 2). 
Table 1

Student Learning Achievement Every Cycle

\begin{tabular}{|c|c|c|c|c|c|c|c|c|c|c|c|}
\hline No & Cycle I & Cycle II & No & Cycle I & Cycle II & No & Cycle I & Cycle II & No & Cycle I & Cycle II \\
\hline 1 & 52 & 83 & 9 & 52 & 77 & 17 & 63 & 92 & 25 & 57 & 73 \\
\hline 2 & 62 & 88 & 10 & 80 & 92 & 18 & 57 & 80 & 26 & 62 & 93 \\
\hline 3 & 60 & 93 & 11 & 57 & 80 & 19 & 55 & 80 & 27 & 70 & 82 \\
\hline 4 & 57 & 80 & 12 & 73 & 90 & 20 & 78 & 87 & 28 & 52 & 82 \\
\hline 5 & 68 & 88 & 13 & 47 & 78 & 21 & 67 & 82 & 29 & 65 & 83 \\
\hline 6 & 53 & 80 & 14 & 72 & 85 & 22 & 65 & 87 & 30 & 68 & 87 \\
\hline 7 & 58 & 75 & 15 & 67 & 82 & 23 & 64 & 88 & 31 & 58 & 83 \\
\hline 8 & 50 & 75 & 16 & 63 & 77 & 24 & 66 & 88 & $\bar{X}$ & 61,87 & 83,55 \\
\hline
\end{tabular}

Table 2

Paired-Samples T Test Cycle I and Cycle II

\begin{tabular}{cccccccc}
\hline Cycle & $\mathbf{N}$ & Average & Min & Max & SD & p \\
\hline I & 31 & 61,87 & 47 & 80 & 8.09 & 0,000 \\
\hline II & 31 & 83,55 & 73 & 93 & 5.56 & \\
\hline
\end{tabular}

Based on the results of paired-samples t test analysis using a significance level of 0.05 can be seen that the value of significance obtained by $0.000<0.05$. So Ho rejected and Ha not rejected (Santoso, 2000). So it can be concluded that there is an increase in student achievement in the lecture by applying a lesson-based learning-based learning.

\section{DISCUSSION}

Instructional Management Based Lesson Study

The basic concept of the lesson study is to see how to improve and develop lessons in real situations (Nesusin, et al., 2014). Lesson study is a collaborative activity of educators to develop learning. Lesson study has been implemented as a viable approach to support teachers' professional development (Saito and Atencio, 2013). The teachers eventually implemented these plans in the classroom and then reflected on the lessons together (Saito and Atencio, 2013). The process of lesson study is: (1) defining the problem; (2) planning the lesson; (3) teaching the lesson; (4) evaluating the lesson and reflecting on its effect; and (5) revising the lesson (Norwich and Ylonen, 2013; Nesusin, et al., 2014; Murata, 2011). The lesson study cycle is carried out through activities: planning-doing-seeing (Saito, et al., 2006). Lesson study process it includes cycles composed of several phases: collaborative planning, lesson observation by colleagues and other knowledgeable advisors, analytic reflection, and ongoing revision (Fernandez, 2010; Lewis, 2002; Stigler and Hiebert, 1999).

Lesson study based learning process is cyclical i.e. lesson planning, learning implementation (do, open class), and evaluation of learning (see). The main stages of the process of lesson study, namely: (1) preparation (preparation / plan); (2) learning lessons; and (3) evaluation (review session) (Baba, 2007). Lesson study is a learning program that involves a team or learning together from a learning that is done, both on learning by himself and other people's learning, from the preparation to the implementation of learning and reflection on the learning. Lesson studybased learning is a collaborative design learning activity, initiating preparing for teaching, conducting learning, observing the learning process, evaluating learning, and analyzing learning outcomes (Haryoto, et al., 2010; Gunawan, 2017).

Characteristics of lesson study-based instructional management is collaborative educators plan learning, implement learning, and reflect on learning (Ariyanto, 2012). Lesson study learning process is collaborative educators: (1) formulate learning objectives; (2) developing a research lesson plan to realize the objectives; and (3) conducting a research lesson with the lesson study participants to obtain evidence of the learning progress of the learners (Lewis, 2002). Lesson study management is a process of managing lesson study starting planning, implementation, and evaluating (Suryanti, 2012). Lesson study management is implemented with the principle of collegiality, collaborative, mutual learning, and sustainable. Lesson study lesson management is the collaborative process of a group of lecturers identifying learning problems, designing learning scenarios; Educate learners according to scenarios, evaluate and revise learning scenarios, revise revised learning scenarios, evaluate learning again, and disseminate the results to other lecturers (Anggara and Chotimah, 2012; Gunawan, 2016a; Gunawan, 2017).

Lesson study management aims to transform the planned curriculum into a curriculum that is implemented in learning and then there is an evaluation of the learning activities that have been done (Firman, 2007; Gunawan, 2016b). Lesson study learning is a collaborative learning that has stages: plan (plan), do (implementation), and see (reflection). Lesson study is a collaborative activity undertaken by a group of educators in order to improve the performance and quality of their learning which in turn can improve their competence and professionalism (Mahmudi, 2009). The purpose of lesson study is to: (1) gain a better understanding of how students learn and lecturers teach; (2) to obtain certain outcomes that benefit other professors in carrying out learning; (3) improving systematic learning; and (4) build a pedagogical knowledge, ie lecturers can gain knowledge from other lecturers (Purwati and Supandi, 2011). 
The benefits of lesson study are: (1) effective ways to improve the quality of lecturers' learning and student learning activities; and (2) accelerate maturation and maturation for young lecturers. Lesson study is a staff development program, as the implementation leaves a significant impact on the quality of teachers and teaching, this concept has been adopted by other countries and has become a model to improve the quality of education and teaching (Copriady, 2013). Lesson study a good idea; teachers with a common focus meet and plan lessons together; these lessons may have a focus on building skills or understanding, and are known as research lessons, which are taught by one, and observed by not only all of the teachers who are doing the planning, but also by observers who, at one end of the spectrum, may come only from the teachers' own school, or, at the other end (Doig and Groves, 2011).

The systematic process of lesson study management is the collaborative work of educators to develop plans and learning tools, observing, reflecting and revising the learning plan in a cyclical, continuous way (Malahayati, 2015). Lesson study needs to be developed to improve the quality of learning by educators in order to become professional educators (Winarsih and Mulyani, 2012). If it refers to the lesson study cycle, then the lesson study activities contain understanding as a study that attempts to study the practice of learning in order to develop better teaching implementation. This is confirmed by Lewis et al. which states that in which they propose three types of research to sustain lesson study practice: (1) expansion of a descriptive knowledge base; (2) explication of the innovation's mechanism; and (3) iterative cycles of improvement research (Suratno, 2012).

The thing to note is that there are differences in lesson study with classroom action research. Lesson study is more emphasized on efforts to improve the ability of education in developing learning activities, while classroom action research is a research activity that aims to solve learning problems and is pragmatic. This is reinforced by Sriyati (2014) which states that lesson study is a strategy to improve the professionalism of educators through learning activities from other people's learning, while classroom action research is activity based on research. Actually the principle difference between classroom action research and lesson study is research-based classroom action research, while lesson study is not always researchbased and lesson study has wider coverage than classroom action research (Sriyati, 2014).

Lesson study-based learning is a collaborative process of a group of teachers to collectively: (1) identify learning problems felt by the teacher; (2) planning the learning steps, as a means of solving the identified problem; (3) carry out the learning done by the model teacher observed by the observer teacher; (4) evaluating the learning process that has been done; (5) improving learning planning based on evaluation results; (6) carrying out more learning; (7) reevaluating the lessons learned; and (8) disseminate the experience and findings of the evaluation to other teachers (Mahmudi, 2015). Lesson study is understood as enhancing the school based approach for improvement of teaching as for professional development (Isoda, 2010).

\section{The Application of Instructional Management Based Lesson Study and its Impact with Student Learning Achievement}

Lesson study provides a better understanding of how students learn and lecturers teach. Certain outcomes are beneficial to other lecturers in carrying out learning, improving the quality of learning in a systematic and comprehensive way, through the innovation of learning methods, instructional media, and building a pedagogical knowledge, where a lecturer can draw knowledge from other professors, or even a lecturer learn from students. So in the lesson study activities of lecturers other than teaching also learn, both to other lecturers and students. Teachers are no longer teaching people, but people who teach themselves through dialogue with the disciples, who in turn are taught in addition to their teaching (Freire, 2013).

Waterman (2011) concluded that the application of lesson study can improve student's learning achievement. A good learning process will improve student achievement (Huitt, et al., 2009; Smith, 2008). Application of lesson-based instructional management can improve academic achievement (Jung, et al., 2015; Smith, 2008). Lesson-based learning can improve student achievement (Smith, 2008); Changing learning situations (Dana and YendolSilva, 2003); and affect student learning climate in the classroom (Meyer and Wilkerson, 2011). Lecturers with a collegial learning plan significantly influence student achievement (Reeves, et al., 2017; Tygret, 2017). A lecturer to become a professional requires a long journey in his career and makes his students excel (Judge and Dalli, 2016; Gunawan and Benty, 2017).

Lesson study-based learning can improve students' understanding of learning (Gonzalez and Deal, 2017; Gunawan, 2016a). Learners through lesson study can improve problem solving skills through project based learning method (Takahashi and Yoshida, 2004; Malahayati, 2015). Lesson study can explore students' activeness and learning achievement (Leavy and Hourigan, 2016). Lesson study-based demonstration learning can improve student achievement (Bruce, et al., 2009). The improvement of learning achievement is shown by the increase of the average test scores in each class after the learning process is carried out with the lesson study (Rahayu, et al., 2012). The implementation of lesson study can improve the quality of learning done by model teachers seen from student learning activities (Azis, et al., 2013; Gunawan, 2015).

\section{CONCLUSION}

Based on the results of the study concluded that: (1) the process of instructional management based on lesson study is cyclical i.e. lesson plan, learning implementation (do, open class), and learning evaluation (see); and (2) there is improvement of student achievement by applying instructional 
management based lesson study. Lecturer's teaching style has a significant influence on student achievement.

\section{REFERENCES}

[1] Andersson, C., and Palm, T. 2017. The Impact of Formative Assessment on Student Achievement: A Study of the Effects of Changes to Classroom Practice after a Comprehensive Professional Development Programme. Learning and Instruction, 49, 92-102.

[2] Anggara, R. A., and Chotimah, U. 2012. Penerapan Lesson Study Berbasis Musyawarah Guru Mata Pelajaran (MGMP) terhadap Peningkatan Kompetensi Profesional Guru PKn SMP Se-Kabupaten Ogan Ilir. Jurnal Forum Sosial, 5(2), 188-197.

[3] Ariyanto, S. Y. 2012. Pengelolaan Pengembangan Pembelajaran Pendidikan Kewarganegaraan Berbasis Lesson Study. Thesis. Surakarta: Postgraduate Program, Muhammadiyah University of Surakarta.

[4] Azis, A. A., Adnan, Abd Muis, Musawwir, and Faisal. 2013. Penerapan Pembelajaran Kolaboratif untuk Meningkatkan Aktifitas Belajar Siswa Kelas XI IPA 3 Melalui Lesson Study Berbasis Sekolah di SMA Negeri 8 Makassar. Jurnal Bionature, 14(1), 38-43.

[5] Baba, T. 2007. How is Lesson Study Implemented? In Isoda, M., Stephen, M., Ohara, Y., and Miyakawa, T., (Eds). Japanese Lesson Study in Mathematics its Impact, Diversity and Potential for Educational Improvement. New Jersey: World Scientific Publishing.

[6] Bruce, C. D., Ross, J., Flynn, T., and McPherson, R. 2009. Lesson Study and Demonstration Classrooms: Examining the Effects of Two Models of Teacher Professional Development. Research report. Toronto: University of Toronto.

[7] Bjuland, R., and Mosvold, R. 2015. Lesson Study in Teacher Education: Learning from a Challenging Case. Teaching and Teacher Education, 52, 83-90.

[8] Copriady, J. 2013. The Implementation of Lesson Study Programme for Developing Professionalism in Teaching Profession. Asian Social Science, 9(12), 176186.

[9] Dana, N. F., and Yendol-Silva, D. 2003. The Reflective Educator's Guide to Classroom Research: Learning to Teach and Teaching to Learn Through Practitioner Inquiry. Thousand Oaks: Corwin Press.

[10] Danarwati, Y. S. 2016. Manajemen Pembelajaran dalam Upaya Meningkatkan Mutu Pendidikan. Retrieved December 26, 2016, from http://stiaasmisolo.ac.id/jurnal/index.php/jmbb/article/download/ 21/19).

[11] Doig, B., and Groves, S. 2011. Japanese Lesson Study: Teacher Professional Development through Communities of Inquiry. Mathematics Teacher Education and Development, 13(1): 77-93.

[12] Feng, H., and Li, J. 2016. Head Teachers, Peer Effects, and Student Achievement. China Economic Review, 41, 268-283.

[13] Fernandez, M. L. 2010. Investigating How and What Prospective Teachers Learn through Microteaching Lesson Study. Teaching and Teacher Education, 26, 351-362.

[14] Firman, H. 2007. Critical Success Factors untuk Pengembangan Lesson Study Berbasis MGMP: Pelajaran yang Dipetik dari Kabupaten Sumedang. Paper National Seminar Exchange of Experiences on Best Practices of Lesson Study, Indonesia University of Education, Bandung, July 21.

[15] Freire, P. 2013. Pendidikan Kaum Tertindas. Jakarta: Penerbit Pustaka LP3ES Indonesia.
[16] Fong, C. J., Kim, Y., Davis, C. W., Hoang, T., and Kim, Y. W. 2017. A Meta-Analysis on Critical Thinking and Community College Student Achievement. Thinking Skills and Creativity, 44(3), 139.

[17] Gasevic, D., Mirriahi, N., Dawson, S., and Joksimovic, S. 2016. Effects of Instructional Conditions and Experience on the Adoption of a Learning Tool. Computers in Human Behavior, 43, 1-14.

[18] Gonzalez, G., and Deal, J. T. 2017. Using a Creativity Framework to Promote Teacher Learning in Lesson Study. Thinking Skills and Creativity, 43(7), 1-46.

[19] Grönqvist, E., and Vlachos, J. 2016. One Size Fits All? The Effects of Teachers' Cognitive and Social Abilities on Student Achievement. Labour Economics, 56(2), 131.

[20] Gunawan, I. 2014. Pengaruh Supervisi Pengajaran dan Kemampuan Guru Mengelola Kelas terhadap Motivasi Belajar Siswa. Ilmu Pendidikan Jurnal Kajian Teori dan Praktik Kependidikan, 41(1), 44-52.

[21] Gunawan, I. 2015. Values and Ethics in Educational Leadership: An Idea of Character Building of Students. Conference Proceedings Character Education in Indonesia Concepts and Applications in Primary Schools, IKIP PGRI MADIUN, 9 June, p. 1-13.

[22] Gunawan, I. 2016a. Manajemen Kelas. Malang: Universitas Negeri Malang.

[23] Gunawan, I. 2016b. Model of Educational Leadership in the Implementation of Curriculum 2013. Proceedings The $4^{\text {th }}$ International Conference Language, Society, and Culture in Asian Contexts (LSCAC 2016) on Cultivating and Casting Asian Diversities: Empowering the Asians, 24-25 Mei, p. 1109-1118.

[24] Gunawan, I. 2017. Instructional Management in Indonesia: A Case Study. Journal of Arts, Science and Commerce, 8(1), 99-107.

[25] Gunawan, I., and Benty, D. D. N. 2017. Manajemen Pendidikan: Suatu Pengantar Praktik. Bandung: Alfabeta.

[26] Gunawan, I., Suraya, S. N., and Tryanasari, D. 2014. Hubungan Kemampuan Berpikir Kreatif dan Kritis dengan Prestasi Belajar Mahasiswa pada Matakuliah Konsep Sains II, Premiere Educandum, 4(1), 1-32.

[27] Hakim, L., and Dalli, C. 2016. To be Professional is a Never-Ending Journey: Indonesian Early Childhood Practitioners' Views about the Attitudes and Behaviours of a Professional Teacher. Early Years, An International Research Journal, 33(1), 1-14.

[28] Haryoto, Lestari, M. D., and Suseno, N. A. 2010. Pengelolaan Pembelajaran Lesson Study Mata Pelajaran IPA di SMA. Widyatama, 19(1), 58-65.

[29] Hernández, M. M., Valiente, C., Eisenberg, N., Berger, R. H., Spinrad, T. L., VanSchyndel, S. K., Silva, K. M., Southworth, J., and Thompson, M. S. 2017. Elementary Students' Effortful Control and Academic Achievement: The Mediating Role of Teacher-Student Relationship Quality. Early Childhood Research Quarterly, 40, 98-109.

[30] Huitt, W., Huitt, M., Monetti, D., and Hummel, J. 2009. A Systems-Based Synthesis of Research Related to Improving Students' Academic Performance. Paper presented at the $3^{\text {rd }}$ International City Break Conference sponsored by the Athens Institute for Education and Research (ATINER), October 16-19, Athens, Greece. Retrieved December 2, 2016, from http://www.edpsycinteractive.org/papers/improvingschool-achievement.pdf.

[31] Isoda, M. 2010. Lesson Study: Problem Solving Approaches in Mathematics Education as a Japanese Experience. International Conference on Mathematics 
Education Research 2010 (ICMER 2010). Procedia Social and Behavioral Sciences, p. 3375-3380, Retrieved December 2, 2016, from (http://www.sciencedirect.com).

[32] Jang, Y. J., Lee, W. G., and Kim, J. 2015. Assessing the Usefulness of Object-based Programming Education using Arduino. Indian Journal of Science and Technology, 8(1), 89-96.

[33] Jung, H., Kwauk, C., Nuran, A., Robinson, J. P. Schouten, M., and Tanjeb, S. I. 2015. Lesson Study: Scaling up Peer-to-Peer Learning for Teachers in Zambia. Tokyo: Japan International Cooperation Agency (JICA), Universal Education.

[34] Kemmis, S., and McTaggart, R. 2014. The Action Research Planner. Victoria: Deakin University Press.

[35] Khan, A. 2012. Instructional Management of a Private and A Government Secondary School Principal in Northern Pakistan. International Journal of Educational Development, 32, 120-131.

[36] Leavy, A. M., and Hourigan, M. 2016. Using Lesson Study to Support Knowledge Development in Initial Teacher Education: Insights from Early Number Classrooms. Teaching and Teacher Education, 57, 161175.

[37] Lewis, C. C. 2002. Lesson Study: A Handbook of Teacher-Led Instructional Change. Philadelphia Research for Better Schools, Inc.

[38] Mahmudi, A. 2009. Mengembangkan Kompetensi Guru Melalui Lesson Study. Forum Kependidikan, 28(2), 84-89.

[39] Mahmudi, A. 2015. Lesson Study. Retrieved May 25, 2016, from http://staff.uny.ac.id/sites/default/files/ tmp/Lesson-Study-MGMP-Jetis-2006_1.pdf).

[40] Malahayati, E. N. 2015. Meningkatkan Kemampuan Memecahkan Masalah melalui Metode Project Based Learning Berbasis Lesson Study. Konstruktivisme, 7(1), 52-61.

[41] Martin, N. K., and Sass, D. A. 2010. Construct Validation of the Behavior and Instructional Management Scale. Teaching and Teacher Education, 26, 1124-1135.

[42] Martin, N. K., Sass, D. A., and Schmitt, T. A. 2012 Teacher Efficacy in Student Engagement, Instructional Management, Student Stressors, and Burnout: A Theoretical Model Using In-Class Variables to Predict Teachers' Intent-to-Leave. Teaching and Teacher Education, 28, 546-559.

[43] Meyer, R. D., dan Wilkerson, T. L. 2011. Lesson Study: The Impact on Teachers' Knowledge for Teaching Mathematics. In Hart, L. C. (Eds.), Lesson Study Research and Practice in Mathematics Education. New York: Springer.

[44] Murata, A. 2010. Teacher Learning with Lesson Study. Procedia - Social and Behavioral Sciences, Retrieved December 20, 2016, from http://www.sciencedirect.com.

[45] Murata, A. 2011. Introduction: Conceptual Overview of Lesson Study. In Hart, L. C., Alston, A. S., and Murata, A. (Eds.)., Lesson Study Research and Practice in Mathematics Education: Learning Together. New York: Springer

[46] Nesusin, N., Intrarakhamhaeng, P., Supadol, P., Piengkes, N., and Poonpipathana, S. 2014. Development of Lesson Plans by the Lesson Study Approach for the $6^{\text {th }}$ Grade Students in Social Study Subject Based on Open Approach Innovation. $5^{\text {th }}$ World Conference on Educational Sciences - WCES 2013. Procedia - Social and Behavioral Sciences, p. 14111415, Retrieved December 25, 2016, from http://www.sciencedirect.com.
[47] Norwich, B., and Ylonen, A. 2013. Design Based Research to Develop the Teaching of Pupils with Moderate Learning Difficulties: Evaluating Lesson Study in Terms of Pupil, Teacher and School Outcomes. Teaching and Teacher Education, 34, 162173.

[48] Olelewe, C. J., and Agomuo, E. E. 2016. Effects of BLearning and F2F Learning Environments on Students' Achievement in QBASIC Programming. Computers and Education, 103, 76-86.

[49] Purwati, H., and Supandi. 2011. Meningkatkan Kompetensi dan Profesionalisme Dosen melalui Lesson Study. Aksioma, 2(2), 1-12.

[50] Rahardjo, M. 2012. Model Pembelajaran Inovatif Yogyakarta: Gava Media.

[51] Rahayu, E. F. 2015. Manajemen Pembelajaran dalam Rangka Pengembangan Kecerdasan Majemuk Peserta Didik. Manajemen Pendidikan, 24(5), 357-366.

[52] Rahayu, P., Mulyani, S., and Miswadi, S. S. 2012. Pengembangan Pembelajaran IPA Terpadu dengan Menggunakan Model Pembelajaran Problem Base Melalui Lesson Study. Jurnal Pendidikan IPA Indonesia, 1(1), 63-70.

[53] Reeves, P. M., Pun, W. H., and Chung, K. S. 2017. Influence of Teacher Collaboration on Job Satisfaction and Student Achievement. Teaching and Teacher Education, 67, 227-236.

[54] Rury, J. L. 2013. Education and Social Change: Contours in the History of American Schooling. New York: Routledge.

[55] Saito, E., and Atencio, M. 2013. A Conceptual Discussion of Lesson Study from a Micro-Political Perspective: Implications for Teacher Development and Pupil Learning. Teaching and Teacher Education, 31, 87-95.

[56] Saito, E., Harun, I., Kuboki, I., and Tachibana, H. 2006. Indonesian Lesson Study in Practice: Case Study of Indonesian Mathematics Science Teacher Education Project. Journal of In-Service Education, 32(2), 17184.

[57] Santoso, S. 2000. Buku Latihan SPSS Statistik Parametrik. Jakarta: Gramedia.

[58] Sarstedt, M., and Mooi, E. 2014. A Concise Guide to Market Research: The Process, Data, and Methods Using IBM SPSS Statistics. New York: Springer.

[59] Sass, D. A., Lopes, J., Oliveira, C., and Martin, N. K. 2016. An Evaluation of the Behavior and Instructional Management Scale's Psychometric Properties using Portuguese Teachers. Teaching and Teacher Education, 55, 279-290.

[60] Smith, R. R. 2008. Lesson Study: Professional Development for Empowering Teachers and Improving Classroom Practice. Dissertation. Florida: College Of Education, Florida State University.

[61] Sriyati, S. 2014. Bagaimana Implementasi Penelitian Tindakan Kelas dalam Aktifitas Lessons Study? Jurnal Pengajaran MIPA, 19(1), 61-68.

[62] Stigler, J. W., and Hiebert, J. 1999. The Teaching Gap. New York: The Free Press.

[63] Suratno, T. 2012. Lesson Study in Indonesia: An Indonesia University of Education Experience. International Journal for Lesson and Learning Studies, 1(3), 196-215.

[64] Suryanti, E. W. 2012. Manajemen Lesson Study Berbasis Sekolah: Studi Multi Situs di SMA Laboratorium UM dan SMA Negeri 1 Grati Pasuruan. Thesis. Malang: Postgraduate Program, State University of Malang. 
[65] Takahashi, A., and Yoshida, M. 2004). Ideas for Establishing Lesson-Study Communities. Teaching Children Mathematics, 45(3), 436-443.

[66] Tygret, J. A. 2017. The Influence of Student Teachers on Student Achievement: A Case Study of Teacher Perspectives. Teaching and Teacher Education, 66, 117-126.

[67] Waterman, S. 2011. A Study of Lesson Study's Impact on Student Achievement. Retrieved December 20, 2016, from

https://www.ets.org/flicc/rsc/pdfs/A_study_lesson_stud ys_impact_student_achievement.pdf.

[68] Widodo, S. F. A. 2016. Manajemen Pembelajaran Pendidikan Agama Islam di Perguruan Tinggi Umum. Retrieved December 27, 2016, from http://staff.uny.ac.id/sites/default/files/pendidikan/mana jemen-pembelajaran-pendidikan-agama-islam.pdf.

[69] Winarsih, A., and Mulyani, S. 2012. Peningkatan Profesionalisme Guru IPA Melalui Lesson Study dalam Pengembangan Model Pembelajaran PBI. Jurnal Pendidikan IPA Indonesia, 1(1), 43-50.

[70] Yoshida, M., and Fernandez, C. 2016. Lesson Study: An Introduction. Tokyo: Global Education Resources. 